\title{
Centro de Acogida para Inmigrantes
}

\author{
Carolina Escalona V. / Profesor Guía: Humberto Eliash
}

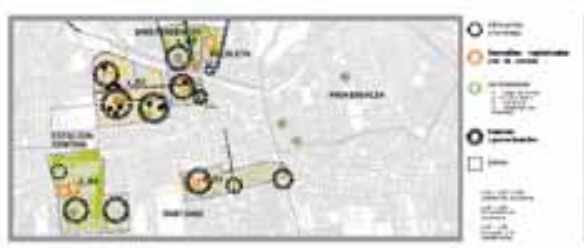

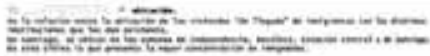

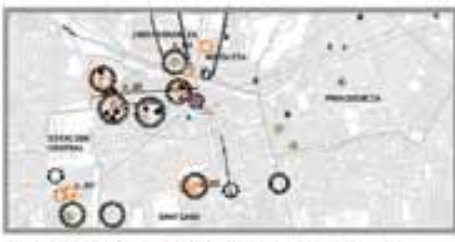

ME:FE:

遏

El ser humano desde sus orígenes es nómade: desplazarse por el mundo es una característica de todo los tiempos y ha sido un importante factor para la construcción de la historia y la cultura de la humanidad. Los movimientos migratorios están motivados por una constante búsqueda de mejores oportunidades y condiciones de vida, seguridad económica, política y social y, en muchos casos, el resguardo de la integridad personal.

Con la globalización, el movimiento de capitales y bienes se ha acelerado, facilitando el desplazamiento de los seres humanos por el mundo. Ya no es extraño encontrar en nuestra ciudades personas de otros lugares del planeta: olores, colores y estilos de vida distintos a los nuestros comienzan a ser parte de nuestros paisajes urbanos.
Este contexto transforma los tradicionales patrones de comportamiento que situaba al inmigrante como un colono que se trasladaba con toda su familia a algún lugar remoto, por nuevas dinámicas de movilidad, tales como migración circular, temporal o de retorno.

Es interesante en este escenario, el nuevo rol que Chile está desempeñando dentro de los movimientos migratorios internacionales: durante los últimos 10 años se ha transformado en un punto de interés para el asentamiento transitorio y permanente de los extranjeros. Es en esta última década también que, la migración europea comenzó a disminuir por los flujos de migración de América Latina. Actualmente cerca del $70 \%$ de la migración, proviene de la región.

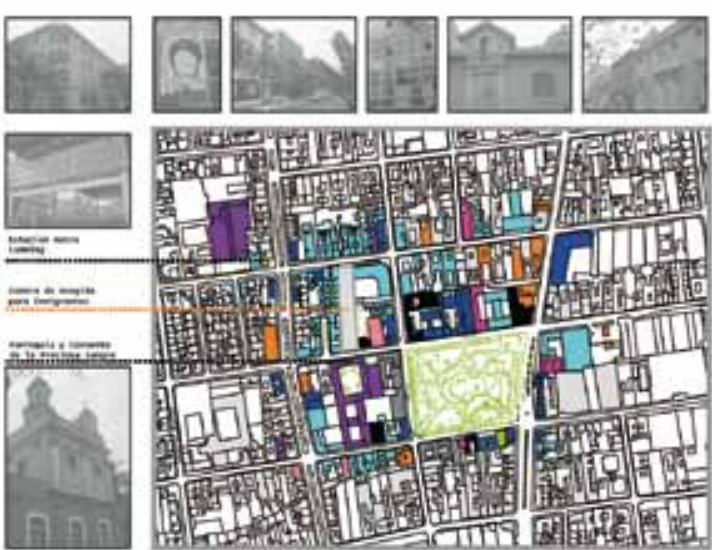

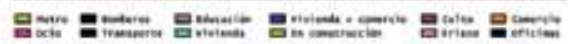

A la problemática de la migración, es inherente la problemática social de la integración, tolerancia y aceptación de la diversidad. Hoy en Chile estamos frente a este desafió: comprender la problemática de la inmigración en todas sus dimensiones, y acoger a los seres humanos que buscan en nuestro país la esperanza de una vida mejor.

El proyecto es una respuesta a la problemática de intregración social de los inmigrantes que llegan a Santiago y se encuentran en situación de vulnerabilidad. Recoge las distintas dimensiones planteadas como urgencias, en cuanto a la asistencia, el primer refugio temporal = habitación de tránsito, al desafío a la multiculturalidad y a la sensibilización de la sociedad chilena de participar y pensar que país queremos construir, abriendo espacios de encuentro, intercambio, debate, opinión y reflexión. 

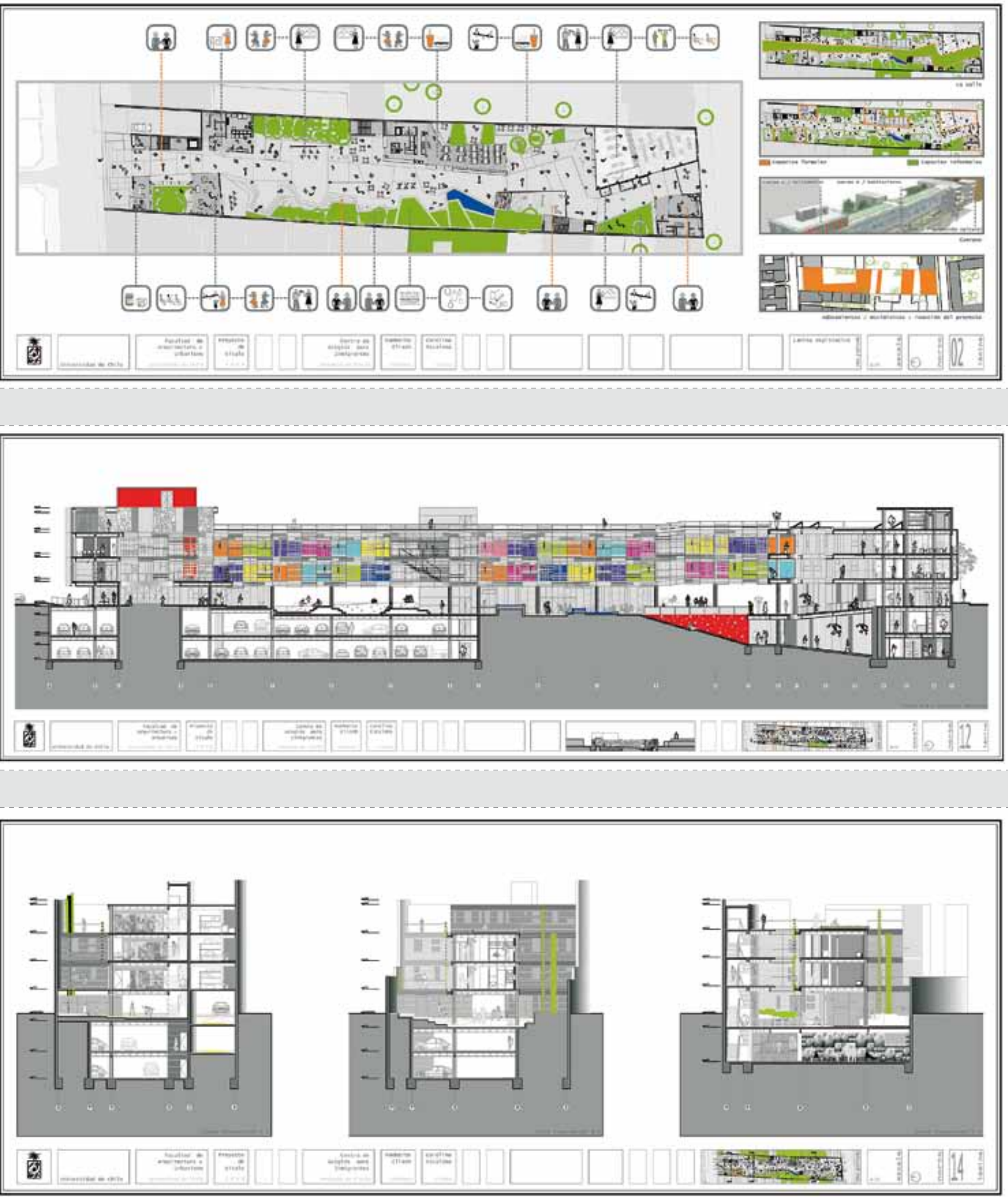